\title{
Building A COMPETENCE CENTER For Wiliams Syndrome at THE HOCHSCHUle ZitTAu/GöRlitZ - CURRENT RESEARCh, TeACHING AND ThIRd Mission
}

\author{
Ingolf Prosetzky ${ }^{1}$; Vera Danielsmeier ${ }^{2}$ \\ ${ }^{1}$ University of Applied Sciences Zittau/Görlitz, HSZG, \\ Faculty of Social Sciences, Heilpädagogik / Inclusion Studies, \\ Furtstraße 2, 02806 Görlitz, Germany \\ ${ }^{2}$ University of Applied Sciences Zittau/Görlitz, HSZG, \\ TRAWOS Institute, \\ Brückenstraße 1, D-02826 Görlitz, Germany \\ e-mail: ${ }^{1}$ Ingolf.Prosetzky@hszg.de; ${ }^{2}$ Vera.Danielsmeier@hszg.de
}

\begin{abstract}
Williams Syndrome (WS) is a rare neurodevelopmental disorder based on a gene loss on chromosome 7, which occurs in 1 of 7,500 live births. The WS phenotype is typically associated with moderate mental disability, cardiac problems, hyper social behavior, anxieties, and a need for lifelong support. Current research focuses mainly on clinical characteristics, thus providing important implications for medical management. Parents, therapists and professional caregivers are able to find very few usable implications for everyday-life challenges though. The authors aim to raise research questions and help to bridge this gap in the long term. Therefore they are engaged in building a competence center for WS at the University of Applied Sciences Zittau/Görlitz (HSZG). This article outlines the starting point and main idea, as well as completed, ongoing and planned scientific and supportive activities.
\end{abstract}

\section{Keywords}

Williams Syndrome; Williams Beuren syndrome; Development; Neurodevelopmental disorder; Basic research; Applied science; Mixed-methods design; Qualitative research.

\section{Introduction}

This article reports on the process of our activities for the scientific investigation of Williams syndrome, and on the knowledge transfer to individuals with WS, their families and professional caregivers. Williams Syndrome (WS, also Williams Beuren Syndrome) is a rare neurodevelopmental disorder (prevalence 1:7.500 [1]) that is associated with a gene loss on chromosome 7 [2]. Clinical characteristics are: a specific "elfin" facial structure and physical anomalies as well as physical health problems, significant abnormalities in brain morphology and function, limitations in cognitive abilities, hyper-social behavior and an increased risk of mental health difficulties [3-6]. In the past few decades, researchers from various scientific disciplines have studied WS for its supposed potential to provide insights into neurocognitive and sociobiological processes and ultimately into the underpinning links between genes, brain and behavior [7-9]. 
Current research focuses mainly on clinical characteristics thus providing important implications for medical management. Parents, therapists and professional caregivers are able to find very few usable implications for everyday-life challenges though.

In 2016 we founded the research group »Williams Beuren Syndrome in Resonanz« (»WBS in Resonanz « for short) to help bridge the gap between scientific results and practical needs of those affected with Williams Syndrome further.

People who live with the conditions of the syndrome very often show a remarkable and unique profile of strengths and weaknesses in single domains. The first chapter outlines the current state of the research in selected scientific areas and defines open questions from the perspective of education and everyday relevance. Chapter two introduces our theoretical considerations, the research group "WBS in Resonanz « and the research project "Challenges, Resources and Goals in Everyday Life with Williams Syndrome - Assessing The Needs for Tailored support«. We then describe the so-called third mission of the universities (knowledge transfer and networking) and our cooperation with national and international WS associations in chapter three. Chapter four provides a short report of this year's 16th National Convention of the U.S. Williams syndromes Association, which took place in Baltimore. In conclusion chapter five gives an overview of our planned research activities.

\section{Current State of Research and Open Questions from the Perspective of Education and Everyday Relevance}

WS, first described at the beginning of the 1960s by cardiologists John Williams [10] and Alois Beuren [11], regarded as a well investigated syndrome despite its rare prevalence. In October 2018, the database Scopus reports more than 1,850 articles with the words 'Williams Beuren Syndrome' or 'Williams Syndrome' in the title. These studies can be principally assigned to the disciplines of basic research medicine (1,199 articles), psychology (498), neurosciences (387), biochemistry, genetics and molecular biology (303) and social sciences (146).

Physically, WS is very often associated with cardiovascular difficulties, tone and growth abnormalities, connective tissue and endocrine, kidney and dental abnormalities [4]. In the field of medicine, various surgical (operation), medicinal and physiotherapeutical treatments (conservative therapy) have been developed into interventional and preventative possibilities.

(Neuro-)Psychologically, WS is associated with unique cognitive and personality profiles, relatively independent of IQ, which include intellectual disability and weaknesses in visualspatial skills (drawing, mathematics, geometry, rotation of objects, navigation, position in space, route relations), but not in all functions of that domain: those with the condition display for instance relative strengths in face perception and object recognition [12-14]. The reasons for the visuoconstructive deficits are well explained [9]. Neurobiological "assessment of visual processing with fMRI showed isolated hypoactivation in WS in the parietal portion of the dorsal stream. In the immediately adjacent parietooccipital/intraparietal sulcus, structural neuroimaging showed a gray matter volume reduction in participants with WS. Path analysis demonstrated that the functional abnormalities could be attributed to impaired input from this structurally altered region." [15]

In the domain of language they present with delayed and atypical language development (especially verbal comprehension), but they show relative strengths in auditory short-term memory and pragmatics $[16,17]$.

Sounds and music usually play an important role in lives of individuals with WS [18, 19]. Neurological auditory processing is found to be abnormal in WS [20, 21]. 91\% of children 
with WS, compared to 2-4\% of children without a disability, experience feelings of intense stress and anxiety when exposed to sounds that are normally not found aversive (Odynacusis and Auditory Allodynia) [18]. These aversions are reported to be highly limiting in everydaylife and tend to decrease after puberty [22]. Besides these aversions, individuals with WS show an increased interest in music and emotional reactivity to music [19]. The number of individuals with WS who play an instrument, 60\%, is significantly higher than in DownSyndrome and Prader-Willi Syndrome [23]. Musical abilities (perception and production) are as sophisticated as those who are typically developed individuals [24].

Within the last few years, the areas of social behavior and mental health have moved into the focus of the research more and more. Individuals with WS are very often described as overfriendly (frequently termed as "Cocktail party personality") with increased empathy, are reported to display increased sociability towards strangers, leading to increased social vulnerability and, surprisingly, as having big problems developing successful friendships and becoming socially isolated in adulthood. From early childhood, they display elevated anxiety derived from fear and specific phobias: later in life there is a high prevalence of psychiatric symptoms [25-28].

In summary, we actually know more about WS than ever before, particularly about the affected brain and the prevalences of symptoms. This knowledge is based on descriptions of abnormal functions and behavior. Less is known about the interplay of primary lesions or limitations and the genesis of symptoms themselves throughout the developmental pathway.

Could overfriendly behavior be a strategy to gain support as compensation for the lack of visuospatial skills? Are mood-swings directly related to the gene loss, or, additionally, a response to exclusion and rejection? Which symptoms are actually experienced as problematic by individuals with WS and their caregivers? How do their symptoms affect their quality of life?

These and related questions have not been studied yet. We assume that this level of understanding is key to finding effective support.

"Surprisingly, in the current international move for inclusion, limited research exists on the educational provision and academic achievements of children with WS, including the nonexisting literature on their voices and the perspectives of key stakeholders." [7] And for youth and adults, we can add: How can this be explained?

There is, compared with the research situation of other rare neurodevelopmental disorders, an enormous discrepancy between (a) extensive basic research and occasional applied research, (b) a considerable imbalance between a vast number of descriptive empirical studies compared with a few contributions to theoretical foundations (c) (especially in psychological and neurobiological studies) an intensive focus on status assessment (prevalence) in brain, cognition and behavior while very often questions of development changes, personals sense and motivation are neglected or ignored, because they "conceptually isolate mental systems from their natural context of interrelations with the biological and cultural systems of which they are a part" [29], (d) an absolute dominance of quantitative approaches in the tradition of medical research compared with sociological qualitative approaches [6] and (e) a clear prevalence in favour of cross-sectional studies (studying a group at one time point) compared with longitudinal section studies (studying different individuals at different ages). Altogether, only a few studies exist outside of the laboratory setting which take up everyday relevant complex needs and educational challenges to date. 
However, the lack of consideration for the persons affected, according to participative research, and the marginally developed applied science are a symptom (and at least the consequence) of the underlying epistemological dilemma of Cartesian reductionism.

"Although Cartesian reductionism has been and will continue to be an indispensable tool of scientific analysis, its strength - the isolation of phenomena from complex relations - is also its weakness (...). When Cartesian reductionism is used exclusively as an analytic method, it eliminates an essential characteristic that needs to be understood - the interrelations of psychological systems both internally among component processes and externally with other systems.” [29]

Through this, not only the ethical question about the imbalance between the huge number of basic research projects and the underdeveloped state of the applied science as well as the corresponding less useful outcomes, but also the methodological question about the relationship between description (empirical phenomena) and explanation (theory formation) arises. Basic research does provide the foundation for applied research and development, however. The connection between basic research and applied research is that basic research provides the knowledge for applied research, and that applied research can, among other things, be a catalyst for basic research. The level of scientific knowledge decreases from basic research to applied research, while the degree of concretion and practical relevance continue to increase [30].

Obviously, it seems to be so that, in the case of the social and health dimensions of WS, the basic research can frequently describe in detail but seldom explain phenomena, although it shows itself to be exemplary in many cross-sectional studies. A cross-sectional study is a study type in which a single measurement of the previously defined parameters takes place within a random sample. The challenge for all researchers consists of selecting a representative sample from the population to be examined, on the one hand, although on the other hand, the choice is strongly localized, because the number of possible test persons with rare syndromes is low by definition. It isn't surprising that, when we match individuals with WS of biological ages from 5 to 50 at one point in time to a single measurement of the parameters, that we find an enormously wide range of within-syndrome individual differences.

To say it very clearly, we owe the important knowledge that a within-syndrome heterogeneity exists to the large number of descriptive cross-sectional studies. It is really important to understand that a wide range of options for living and dealing with this syndrome exists, but this explains all or nothing. Frequently, descriptive cross-sectional studies about the phenomena conclude that further empirical studies are necessary to be able to come up with better explanations. But, in the words of Fischer and Bidell [29] "recognizing that phenomena need to be explained is not the same as explaining them." If the basic research does not generate explanatory knowledge about the reasons for developmental delays and the conditions of possibilities for useful interventions and learning processes, then the applied science lacks a basis.

Related to WS, a transformation of the research field already occurred in 2003 when Dykens demanded a greater educational relevance; an expansion of the method spectrum and an analysis of complex connections: The 'whole person' is missing" [31]. This transformation has failed to appear, except for occasional studies, to date [22, 32-34].

\section{Our research and teaching activities}

Prosetzky has delivered one of these contributions to theory formation and to the better understanding of individuals with WS on the basis of the neuropsychological development 
theories of Vygotskij [35-37] and Lurija [38, 39]. From the perspective of cultural and historical neuropsychology, the author developed the idea that difficulties in the spatial domain and the preference for music, over-friendliness and the problems of forming friendships as well as the prevalence of mental health problems do have an inner connection. The key lies in the understanding of the dynamic of symptoms which are strongly influenced by emotions. Through this, the behavior of persons with WS always has a subjective and inner logic and cannot be explained or one-sidedly reduced to causes in gene and brain (more detailed [34]). Supplementary to the theories of Vygotskij and Lurija, the intersubjective concepts attunement and resonance play a large role in this [40]. While recognizing the emotional states of others is a strength for individuals with WS (emotional attunement), recognizing the intentional states of others is a problem (intentional attunement). (Not) being in emotional resonance with others is a very important aspect of individuals with WS and their ability to turn their brains and developing processes "on or off" [34, 41].

Danielsmeier [22] studied the experience of music and sound in WS using a Sequential Mixed Methods Design [42]. She first studied longitudinal quantitative data from 176 individuals with WS and found that aversions towards sounds decreased after puberty. She then selected four adult individuals with WS from the database and interviewed them in order to gain insight into their perspective on the phenomenon and causes for the change. Results showed that the decrease in anxieties was not due to a change in perception, but due to learning autonomous strategies to cope with stressful situations, thus lowering the intensity of aversive reactions. This study suggests Qualitative and Mixed Methods Designs as pathway to understanding symptoms and thus creating practical educational guidance for WS.

In October 2016 we founded the research group »WBS in Resonanz« (www.hszg.de/wbs) at the Faculty of Social Sciences in Görlitz. Generally speaking, six to nine students from the study course Heilpädagogik/Inclusion Studies from different years meet approximately twice per month. The aims and main focuses of the work of the research group are:

- Awareness of the public for WS and the challenges connected with that (early learning centres, Kindergartens, schools, housing options and sheltered workshops (Werkstätten für behinderte Menschen) or supported employment for disabled people

- Regional networking for individuals with WS and their families

- Building international scientific networks

- Enabling of an attractive alternative studying place: studying by participation in research, discovering curiosity and enthusiasm for research (supporting young people in the profession)

- Literature research and evaluation of current international research publications to WS

- Exchange platform for the further development of theoretical and empirical research contributions of one's own (explicitly qualifying research for studying.)

- Development of an educational WS competence and advisory centre in Görlitz.

- Acquisition of subsidies for the execution of research projects.

We were able to undertake the project »Challenges, Resources and Goals in Everyday Life with Williams Syndrome - Assessing the Needs for Tailored Supports « between May and December 2017; made possible by a special funding program of the State Ministry for Science and culture in Saxony. The central idea of the project was an integral, systematic as well as methodical and, as regards content, comprehensive demand analysis. Those who live with WS every day, whether as an individual, a relative or a professional caregiver, have 
already developed individual strategies to handle challenges and thrive from resources. How can we learn from these experiences in order to support other families?

It was consequently the first aim of the project to acquire data to learn from these experiences and make it utilizable for other persons affected. It was the second aim to impulse a methodology discussion in the field of WS research. For an integrated and holistical research, new paradigms must be discussed as well as professional and methodological gaps overcome.

In the context of a Concurrent Mixed Methods design [42] 74 interviews altogether were carried out in two partial studies. The students were actively involved in the creative process of developing semi-structured guidelines for the interviews [43], proof testing and in the work of transcription.

The interviews were carried out with family members during the Bundesverbandstag in Willingen. We asked in the dimensions:

Challenges: What are the most present challenges in everyday life?

Resources: What are helpful resources?

Coping strategies: How did respondents cope with challenges? What was helpful, what not?

Personal goals: What are the individual goals of development for respondents?

Support: How should helpful support be designed?

The interviewing of the professional caregivers was carried out in the North of Germany for organizational reasons. Among others teachers, educators, ergo therapists and physiotherapists, but also members of the volunteer fire brigade were involved here.

Altogether, an impressive data set from qualitative data (1,800 page transcript of 74 interviews) and quantitative data $(N=31)$.

The interviews have been evaluated in five master theses to date, and build the empirical basis for the doctoral thesis of Vera Danielsmeier started in 2017; a cooperative doctoral programme between HSZG and the University of Bremen. (In accordance with university laws in Saxony, particularly gifted graduates from universities of applied science can be admitted to a cooperative doctoral programme in order to complete their doctorate. The HSZG is not currently authorised to offer doctoral studies, for which reason efforts are being made to facilitate cooperative doctoral study programmes with other universities). We plan to have results at the end of 2019.

At present, an educational guide is being prepared in the research group »WBS in Resonanz« from the intermediate reports of the interviews for teachers.

The second aim of the project was achieved through a presentation of a Mixed Methods study on auditive perception at the international WS conference in Madrid, Spain on November 10th and 11th, 2017 [22]. The work was the only study with qualitative methods and open questions presented at the conference. Researchers were highly interested and spoke out for the urgent need for such qualitative and open research projects.

\section{Third Mission: WS family meeting and specialist conference at the HSZG}

Since 1989 the Bundesverband Williams-Beuren-Syndrom e.V. (National Association), founded by parents in Germany, has existed. Currently the association advises and informs over 560 families in different regions into a network and organizes, among others, leisure camps and regional meetings. The National Convention (Bundesverbandstag) of the Association takes place nearly in the middle of Germany geographically (Willingen, Hessen) 
on an extended weekend every three years. There are also comparable organizations in the Czech Republic (http://willik.tym.cz) and Poland (http://www.zespolwilliamsa.org), which are coordinated by the European Federation of Williams Syndrome (http://www.eurowilliams.org).

The family meeting of the regional group Saxony and Saxony-Anhalt took place on the campus of the university in Görlitz from April 20th to 22nd, 2018. 28 families took part in it. Families were supposed to get the opportunity for private exchange on the one hand, and be informed by specialists in WS according to the example of the Bundesverbandstag, on the other hand. With 20 speakers and numerous voluntary helpers from the university, about 130 persons took part. It was the first meeting of this order of magnitude in the New Bundesländer.

The organization and execution of the meeting was carried out in close cooperation with WS regional group and in the context of a study project at the HSZG. Everyone at the organization is involved in the research group »WBS in Resonanz«. To be able to make the meeting according to the wishes and needs of the families, the project team sent a questionnaire out to the families at the end of last year. These results enabled an assessment of the numbers of participants and interests first of all. The project was mainly financed through a self-help promotion of AOK plus. AOK plus is one of the largest health insurance providers in Germany. Among other things the AOK took on a large part of the overnight stay costs of the families, so higher financial barriers did not stand in the way of participation.

The first families arrived on Friday and took part in a guided tour through Görlitz. Saturday morning marked the official start of the meeting with the welcoming speeches of the Saxon state minister Barbara Klepsch, the rector of the university Prof. Dr. Friedrich Albrecht and the chairmen of WS Bundesverband Chris Leber.

After the speeches about pedagogical (author) and medical challenges (Prof. Dr. Rainer Pankau) the parents, grandparents and professional caregivers had the choice between various workshops (for instance »what does WS mean for our family? «, »wills and the law of inheritance $\ll)$.

During the whole of Saturday there was a colorful program for individuals with WS, channels of information as well as game and sports offers. A workshop dealing with digital media, the opportunity to play instruments together, and a workshop for hand printing were on offer. For the siblings a spectacular climbing excursion to the Königshainer Berge was made possible. For the end of the day most families met in a comfortable restaurant in the Görlitz old town.

On Sunday there were further lectures and workshops. For many children the visit to Görlitz zoo was the highlight of the weekend.

The very positive verbal feedback in the final plenary and the written answers in the evaluations show that the meeting was a complete success and repetition is desired from the families. The degree of organisation, the quality of the lectures and the kind atmosphere was stressed particularly positively during the weekend. The amount of choice was a point of criticism for some families, who said it was too big and the information density had been too high at the workshops. In our view, the most important aim, namely of improving regional networking for the families, was achieved. Of the 62 persons who filled out the evaluation form before the meeting, 11 persons had no contact to other families/persons with WS and 24 persons only had contact to 1-2 other families/persons with WS in Görlitz. For most of the students the organizing and volunteering was a very enriching experience according to the theory-practice-transfer. Moreover, many parents agreed in private discussions to be available 
to students as contact persons for possible internships or other parts of their degree program (Bachelor's thesis).

\section{$4 \quad$ Visit the 16. U.S. National Convention of the Williams syndromes association}

To network with specialists in WS and to learn which current research results are being discussed with families and what research is planned for the future, the author visited the US American Williams Syndrome National Convention in Baltimore/Maryland in July 2018.

Approximately 20,000 people live with the WS condition in the USA. The Williams syndrome Association (WSA) was founded at the end of the 1980s and currently has between 3-4,000 members. The National Convention takes place (alternating between the west, the middle, and the east) in different places every two years.

The 16th National Convention was carried out in the Marriott Waterfront hotel in the centre of Baltimore. During the four days, 1,300 family members and professional carers experienced an extraordinarily extensive and varied program of specialist lectures and leisure activities. For people with WS of all ages and their siblings, a colorful leisure program was organized, in which more than 300 volunteers were involved.

The range of topics in the lectures included, among others, medicine (cardiovascular problems, anesthesia), behavioral problems (fears, psychotherapy, psychotropic drugs), financial and legal support and the situation of siblings. In the medical sessions, individual health experience and the quality of life played an important role. It was also noteworthy that several sessions were interdisciplinary with cardiologists, pediatricians and psychologists.

Furthermore, the variety of different formats was impressive, whereby a lot of value was placed on low-threshold and communicative formats. There were e.g. several one-on-one sessions with the opportunity for therapeutic and legal consultations, Question and Answer Sessions and also the lunch and learn format, where family members were able to have lunch and discuss their problems with the experts in a small and informal round.

In order to make the networking of all interested parties as easy as possible, there was a conference app for the smartphone, in which the slides of the speakers were deposited. It is also possible to download all the audio recordings of the convention sessions on the Internet.

Overall, visiting the Convention in the US was a great inspiration and enrichment, also because we are now in contact with other international researchers. Although the WSA offers financial support to families with less financial resources, the high fees for the hotel and the meeting are a financial barrier. We are all the more grateful that the trip to the US was made possible by a generous grant from HSZG.

\section{Conclusion}

Since 2016, we have been on the way to establishing a pedagogical competence center for WS in Görlitz. Through this, we are trying to involve students as actively as possible, as well as raising research questions and closing research gaps. As already mentioned, we are currently busy analyzing the gathered data as well as creating pedagogical guidelines for parents and professional caregivers. We are also organizing the second family meeting of the regional group Saxony and Saxony-Anhalt on the campus of the university of Görlitz on May 11th, 2019. The focus of the conference will be the topic of friendship and loneliness. We are always looking for research partners in Poland and the Czech Republic. The biggest challenge for us is raising funds to receive substantial human and material resources. 


\section{Acknowledgements}

We would like to thank Dr. Rachel Ramsay.

\section{Literature}

[1] STROMME, P.; BJORNSTAD, P. G.; RAMSTAD, K.: Prevalence estimation of Williams syndrome. Journal of Child Neurology. DOI: 10.1177/088307380201700406

[2] EWART, A. K. et al.: Hemizygosity at the elastin locus in a developmental disorder, Williams syndrome. Nature Genetics. DOI: 10.1038/ng0993-11

[3] POBER, B. R.; Williams-Beuren syndrome. The New England Journal of Medicine. DOI: $\underline{10.1056 / N E J M r a 0903074}$

[4] BARAK, B.; FENG, G.: Neurobiology of social behavior abnormalities in autism and Williams syndrome. Nature Neuroscience. DOI: $\underline{10.1038 / \mathrm{nn} .4276}$

[5] MARTENS, M. A.; WILSON, S. J.; REUTENS, D. C.: Research Review: Williams syndrome: a critical review of the cognitive, behavioral, and neuroanatomical phenotype. Journal of Child Psychology and Psychiatry. DOI: 10.1111/j.14697610.2008.01887.x

[6] RIBY, D. M. et al.: The interplay between anxiety and social functioning in Williams syndrome. Journal of Autism and Developmental Disorders. DOI: 10.1007/s10803-013$\underline{1984-7}$

[7] MEYER-LINDENBERG, A.; MERVIS, C. B.; BERMAN, K. F.: Neural mechanisms in Williams syndrome: a unique window to genetic influences on cognition and behaviour. Nature Reviews Neuroscience. DOI: 10.1038/nrn1906

[8] NIKITINA, E. A. et al.: Williams syndrome as a model for elucidation of the pathway genes - the brain - cognitive functions: genetics and epigenetics. Acta Naturae. 2014. Vol. 6, Issue 1, pp. 9-22.

[9] ATKINSON, J.; BRADDICK, O.: From genes to brain development to phenotypic behavior: "dorsal-stream vulnerability" in relation to spatial cognition, attention, and planning of actions in Williams syndrome (WS) and other developmental disorders. Progress in Brain Research. DOI: 10.1016/B978-0-444-53884-0.00029-4

[10] WILliaMS, J. C.; BARRATT-BOYES, B. G.; LOWE, J. B.: Supravalvular aortic stenosis. Circulation. 1961; Vol. 24, pp. 1311-1318.

[11] BEUREN, A. J.; APITZ, J.; HARMJANZ, D.: Supravalvular aortic stenosis in association with mental retardation and a certain facial appearance. Circulation, 1962; Vol. 26, pp. 1235-1240.

[12] LANDAU, B.; FERRARA, K.: Space and Language in Williams syndrome: Insights from typical development. WIREs Cognitive Science. DOI: 10.1002/wcs.1258

[13] LANDAU, B.; HOFFMAN, J. E.; KURZ, N.: Object recognition with severe spatial deficits in Williams syndrome: sparing and breakdown. Cognition. DOI: $10.1016 /$ j.cognition.2005.06.005

[14] FARRAN, E. K. et al.: Route knowledge and configural knowledge in typical and atypical development: a comparison of sparse and rich environments. Journal of Neurodevelopmental Disorders. DOI: 10.1186/s11689-015-9133-6 
[15] MEYER-LINDENBERG, A. et al.: Neural basis of genetically determined visuospatial construction deficit in Williams syndrome. Neuron. DOI: 10.1016/j.neuron.2004.08.014

[16] Van HERWEGEN, J.: Williams syndrome and its cognitive profile: the importance of eye movements. Psychology Research and Behavior Management. DOI: $\underline{10.2147 / P R B M . S 63474}$

[17] BROCK, J.: Language abilities in Williams syndrome: A critical review. Development and Psychopathology. DOI: 10.1017/S095457940707006X

[18] LEVITIN, D. J. et al.: Aversion, awareness, and attraction: Investigating claims of hyperacusis in the Williams syndrome phenotype. Journal of Child Psychology and Psychiatry. DOI: $\underline{10.1111 / \mathrm{j} .1469-7610.2004 .00376 . \mathrm{x}}$

[19] NG, R. et al.: Musicality Correlates With Sociability and Emotionality in Williams Syndrome. Journal of Mental Health Research in Intellectual Disabilities. DOI: $10.1080 / 19315864.2012 .683932$

[20] BELLUGI, U. et al.: Neuropsychological, neurological, and neuroanatomical profile of Williams syndrome. American Journal of Medical Genetics. Supplement, 1990, Vol. 37, Issue S6, pp. 115-125. DOI: 10.1002/ajmg.1320370621

[21] LEVITIN, D. J. et al.: Neural correlates of auditory perception in Williams syndrome: An fMRI study. NeuroImage. DOI: 10.1006/nimg.2002.1297

[22] DANIELSMEIER, V. A.: Das Musik- und Geräuscherleben von Menschen mit Williams-Beuren-Syndrom im Kontext psychischer und sozialer Kontextfaktoren. Eine ressourcenorientierte Studie. Masterthesis, 2014, Universität Bremen: Bremen.

[23] DYKENS, E. M. et al.: Music and anxiety in Williams syndrome: A harmonious or discordant relationship? American Journal on Mental Retardation. DOI: 10.1352/08958017(2005)110[346:MAAIWS]2.0.CO;2

[24] LEVITIN, D. J.; BELLUGI, U.: Musical abilities in individuals with Williams syndrome. Music Perception. DOI: $10.2307 / 40300863$

[25] DYKENS, E. M.: Anxiety, fears, and phobias in persons with Williams syndrome. Developmental Neuropsychology. DOI: 10.1080/87565641.2003.9651896

[26] NG-CORDELL, E. et al.: Anxiety in Williams Syndrome: The Role of Social Behaviour, Executive Functions and Change Over Time. Journal of Autism and Developmental Disorders. DOI: 10.1007/s10803-017-3357-0

[27] ROYSTON, R. et al.: Anxiety Disorders in Williams Syndrome Contrasted with Intellectual Disability and the General Population: A Systematic Review and MetaAnalysis. Journal of Autism and Developmental Disorders. DOI: 10.1007/s10803-016$\underline{2909-Z}$

[28] STINTON, Ch.; ELISON, S.; HOWLIN, P.: Mental health problems in adults with Williams syndrome. American Journal on Intellectual and Developmental Disabilities. DOI: $10.1352 / 1944-7558-115.1 .3$

[29] FISCHER, K. W.; BIDELL, T. R.: Dynamic Development of Action and Thought. Handbook of Child Psychology. DOI: 10.1002/9780470147658.chpsy0107

[30] STANGL, W: Grundlagenforschung. Online Lexikon für Psychologie und Pädagogik. [online]. 2018. [accessed 2018-10-30]. Available from WWW: http://lexikon.stangl.eu/3600/grundlagenforschung 
[31] DYKENS, E. M.: The Williams syndrome behavioral phenotype: the 'whole person' is missing. Current Opinion in Psychiatry. DOI: 10.1097/00001504-200309000-00006

[32] FISHER, M. H. et al.: Experiences of Bullying for Individuals with Williams Syndrome. Journal of Mental Health Research in Intellectual Disabilities. DOI: $10.1080 / 19315864.2016 .1278289$

[33] FISHER, M. H.; MELLO, M. P.; DYKENS, E. M.: Who reports it best? A comparison between parent-report, self-report, and the real life social behaviors of adults with Williams syndrome. Research in Developmental Disabilities. DOI: $10.1016 /$ j.ridd.2014.08.011

[34] PROSETZKY, I.: Mehr als die Summe seiner Symptome: zur kulturhistorischen Neuropsychologie und Pädagogik des Williams-Beuren-Syndroms. Lehmanns Media, Berlin, 2008. ISBN 978-3-86541-628-5.

[35] JANTZEN, W: Kulturhistorische Psychologie heute: Methodologische Erkundungen zu L. S. Vygotskij. Lehmanns Media, Berlin, 2008. ISBN 978-3-86541-240-9.

[36] VYGOTSKIJ, L. S.: Ausgewählte Schriften. Lehmanns Media, Berlin, 2003. ISBN 3936427-49-6.

[37] RIEBER, R. W.; CARTON, A. S.: The diagnostics of development and the pedagogical clinic for difficult children. The collected works of L. S. Vygotsky. Volume 2. The fundamentals of defectology. DOI: 10.1007/978-1-4615-2806-7_20

[38] LURIJA, A. R.: The working brain: an introduction to neuropsychology. Basic Books, New York, 1976. ISBN 97804650920.

[39] LURIJA, A. R.: Higher cortical functions in man. Basic Books, New York, 1966. ISBN 978-1-4615-8579-4.

[40] GALLESE, V.: Intentional attunement: A neurophysiological perspective on social cognition and its disruption in autism. Brain Research. DOI: $10.1016 /$ j.brainres.2006.01.054

[41] RIEBER, R. W.; CARTON, A. S.: The Problem of Mental Retardation. The collected works of L. S. Vygotsky. Volume 2. The fundamentals of defectology. DOI: $\underline{10.1007 / 978-}$ $\underline{1-4615-2806-7 \_19}$

[42] CRESWELL, J. W.: Research design: qualitative, quantitative, and mixed methods approaches. Sage, Los Angeles 2014. ISBN 1452226105.

[43] MRUCK, K.; MEY, G.: Handbuch qualitative Forschung in der Psychologie. VS Verlag, Wiesbaden, 2010. ISBN 9783531167268.

Prof. Dr. Ingolf Prosetzky; Dipl.-Psych. Vera Danielsmeier 


\section{VÝSTAVBA CENTRA PRO WILLIAMSU゚V SYNDROM V HOCHSCHULE ZITTAU/GÖRLITZ - SOUČASNÝ VÝZKUM, VÝUKA A TŘETÍ MISE}

Williamsův syndrom (WS) je vzácná porucha nervové soustavy způsobená ztrátou genu na chromozomu 7, která se vyskytuje u 1 ze 7500 živě narozených dětí. Fenotyp WS je typicky spojen s mírným mentálním postižením, srdečními problémy, hypersociálním chováním, úzkostmi a potřebou péče po celou délku života. Současný výzkum se zaměřuje hlavně na klinické charakteristiky, čímž poskytuje důležité výsledky pro zdravotnický management. Rodiče, terapeuti a profesionální pečovatelé však mohou najít velmi málo použitelných návodů pro výzvy každodenního života. Cílem autorů je položit si výzkumné otázky a pomoci překlenout tyto mezery $\mathrm{v}$ dlouhodobém horizontu. Proto se zabývají budováním kompetenčního centra pro WS na Univerzitě aplikovaných věd Zittau / Görlitz (HSZG). Tento článek popisuje výchozí bod a hlavní myšlenku, stejně jako dokončené, probíhající a plánované vědecké a podpůrné aktivity.

\section{DIE ERRICHTUNG EINES KOMPETENZZENTRUMS ZUR BEHANDLUNG DES WILLIAMS-SYNDROMS AN DER HOCHSCHULE ZITTAU/GÖRLITZ - LAUFENDE FORSCHUNG, UNTERRICHT UND DRITTE MISSION}

Beim Williams-Syndrom (WS) handelt es sich um eine seltene nervliche Entwicklungsstörung, welche auf einem Genverlust am Chromosom 7 beruht. Diese Störung wird bei einer von 7500 Geburten diagnostiziert. Der WS-Phänotyp geht typischerweise einher mit einer mäßigen geistigen Behinderung, Herzproblemen, einem hypersozialen Verhalten, Angstzuständen und dem Bedürfnis nach lebenslanger Unterstützung. Die gegenwärtige Forschung ist hauptsächlich auf die klinischen Charakteristiken gerichtet und bringt so wichtige Folgerungen für das medizinische Management. Eltern, Therapeuten und professionelle Betreuer vermögen freilich nur sehr wenige brauchbare Folgerungen für die Herausforderungen des Alltagslebens $\mathrm{zu}$ finden. Die Autoren zielen darauf ab, Forschungsfragen zu stellen und langfristig diese Lücke zu überbrücken. Daher sind sie damit befasst, an der Hochschule Zittau/Görlitz (HSZG) ein Kompetenzzentrum für das WS einzurichten. Dieser Artikel skizziert den Anfangspunkt und den Hauptgedanken sowie weiterführende und geplante wissenschaftliche unterstützende Aktivitäten.

\section{BUDOWA CENTRUM ZESPOŁU WILLIAMSA W HOCHSCHULE ZITTAU/GÖRLITZ- OBECNE BADANIA, NAUCZANIE I TRZECIA MISJA}

Zespół Williamsa (ZW) to rzadkie zaburzenie układu nerwowego spowodowane mutacją w obrębie chromosomu 7, występujące u 1 na 7500 żywych urodzonych dzieci. Fenotyp ZW jest typowo związany z łagodnym upośledzeniem umysłowym, wadami serca, zaburzeniami zachowania, lękami i konieczną opieką przez całe życie. Obecne badania skupiają się przede wszystkich na cechach klinicznych, dając ważne informacje dla zarządzania medycznego. Jednak rodzice, terapeuci i profesjonalni opiekunowie mogą znaleźć niewiele informacji, jak podołać wyzwaniom życia codziennego. Celem autorów jest sformułowanie pytań badawczych i chęć zagospodarowania tych braków w perspektywie długoterminowej. Dlatego zajmują się oni stworzeniem ośrodka kompetencyjnego dla ZW na Uniwersytecie Nauk Stosowanych Zittau/ Görlitz (HSZG). W niniejszym artykule opisano punkty wyjścia oraz główną ideę a także ukończone, trwające i planowane działania naukowe i wspomagające. 